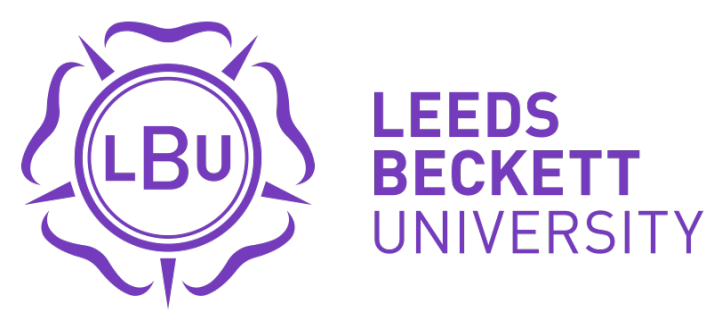

Citation:

Spracklen, K and Robinson, D (2020) Putting faith in vinyl, real ale and live music : a case study of the limits of tourism policy and a critical analysis of new leisure spaces in a northern English town. Tourism, Culture and Communication, 20 (2-3). pp. 151-161. ISSN 1098-304X DOI: https://doi.org/10.3727/109830420X15894802540223

Link to Leeds Beckett Repository record:

https://eprints.leedsbeckett.ac.uk/id/eprint/6597/

Document Version:

Article (Published Version)

Copyright 2020 Cognizant, LLC.

The aim of the Leeds Beckett Repository is to provide open access to our research, as required by funder policies and permitted by publishers and copyright law.

The Leeds Beckett repository holds a wide range of publications, each of which has been checked for copyright and the relevant embargo period has been applied by the Research Services team.

We operate on a standard take-down policy. If you are the author or publisher of an output and you would like it removed from the repository, please contact us and we will investigate on a case-by-case basis.

Each thesis in the repository has been cleared where necessary by the author for third party copyright. If you would like a thesis to be removed from the repository or believe there is an issue with copyright, please contact us on openaccess@leedsbeckett.ac.uk and we will investigate on a case-by-case basis. 


\title{
PUTTING FAITH IN VINYL, REAL ALE, AND LIVE MUSIC: A CASE STUDY OF THE LIMITS OF TOURISM POLICY AND A CRITICAL ANALYSIS OF NEW LEISURE SPACES IN A NORTHERN ENGLISH TOWN
}

\author{
KARL SPRACKLEN* AND DAVE ROBINSON† \\ *Leeds School of Social Sciences, Leeds Beckett University, Leeds, UK \\ $\dagger$ Leeds School of Arts, Leeds Beckett University, Leeds, UK
}

\begin{abstract}
Skipton, on the edge of the Yorkshire Dales National Park, is an old mill town that has seen tourists flocking to it since the arrival of the railway in the 19th century. Like many other old mill towns in northern England, Skipton has lost those mills-as-factories and the workers in them-and has struggled to retain a sustainable local economy. At the same time, Skipton has become increasingly gentrified, and has become a focus for day visitors and tourists attracted by the beautiful countryside seen when Le Tour de France came through Yorkshire in 2014. In this article, we explore the area of Skipton, dubbed the Canal Quarter. We focus on the leisure spaces that have opened there as attempts to construct alternative, authentic experiences around the consumption of real ale, the performance of live music, and the curation of second-hand vinyl records. We have previously explored how these might be shown to be a space for Habermasian rationality. In this sequel, we use critical theory to show how the alternative, authentic space of vinyl, real ale, and live music has already been compromised by two conflicting hegemonic powers: the cooption of leisure into the economics of tourism and tourism policy, and the meaninglessness of cool capitalism and Bauman's consumer society.
\end{abstract}

\section{Key words: Authenticity; Drinking; Hipsters; Leisure; Tourism; Yorkshire}

Introduction

Yorkshire.com, the website of Welcome to Yorkshire - the official agency promoting tourism in Yorkshire, UK — has this to say about Skipton:

As the gateway to the magnificent Yorkshire Dales, people travel the length and breadth of the country to visit this charming market town. With its famous 900 year old castle, romantic ruined priory and historic cobbled High Street, Skipton is endlessly rich both in history and outstanding natural beauty. (Welcome to Yorkshire, 2019a)

This is a classic piece of hyperbole. Charming means nothing. The "romantic ruined priory" is 6 
miles out of town. The setts on the High Street line the edges of the road, and are usually hard to notice because they are used for parking and market stalls. Skipton is on the edge of the Yorkshire Dales National Park but is also an old West Riding mill town that grew rapidly like every other mill town close to running water and canals at the time (Spracklen, 2016). As well as capitalists finding new places to build factories, and people migrating down the dales to find work, the town has seen tourists flocking to it since the arrival of the railway in the 19th century. Generations of walkers and cyclists came to Skipton because it was a place from which one could reach out into the dales and the hills: technically it is in Airedale, but it is close to Upper Wharfedale. Like many other old mill towns in northern England, Skipton has lost those mills-as-factories and the workers in them - and has struggled to retain a sustainable local economy. There are pockets of long-term deprivation in Skipton, and in the wider Craven District, and the local authorities are keen to find solutions and jobs for multigenerational unemployment as well as deprivation in the outlying rural communities (Great Place, 2018; LEP, 2016). At the same time, Skipton has become increasingly gentrified, and a focus for day visitors and tourists attracted by the beautiful countryside seen when Le Tour de France came through Yorkshire in 2014 (Spracklen, 2019; Whittle, Lomax, Heppenstall, \& Brerton, 2017).

According to its own figures, since Welcome to Yorkshire launched in 2009 "the visitor economy has grown from $£ 5.9 \mathrm{bn}$ to $£ 8 \mathrm{bn}$," and "an additional 4,000 jobs have been created" (Welcome to Yorkshire, 2019b). Commuters working in Bradford and Leeds have always bought houses in Skipton, but the increased focus on Craven as being "the happiest place to live" (Office for National Statistics, 2017), combined with people falling in love with the town as tourists and moving to it, has meant a huge shift in the range of accents and faces in the town. Many of those moving to the town are retirees, selling up down south, and using their capital to trade-up to big houses in Skipton (Gallent \& Robinson, 2012). Others are people who work flexibly, or people who can afford to commute to their places of work in Leeds or even London. There is still a Boyes and a Sports Direct offering bargains, but now there are vegan cafés and fine dining restaurants as Skipton gentrifies.
In this article, we situate ourselves in critical tourism studies (MacCannell, 1973, 2001, 2013; Urry, 1990) as well as critical policy studies (Rose, 1999). We explore the area of Skipton dubbed the Canal Quarter as a space that allows us to explore tourism and leisure policy and the tension with wider social and cultural policies and issues such as gentrification (Skoll \& Korstanje, 2014). We focus on the leisure spaces that have opened there as attempts to construct alternative, authentic experiences around the consumption of real ale, the performance of live music, and the curation of second-hand vinyl records. We have previously explored how these might be shown to be a space for Habermasian communicative rationality (Robinson \& Spracklen, 2019). That is, we used Habermas $(1984,1987)$ as a lens to make sense of the meaning and purpose of leisure, and how different Habermasian rationalities existed in the live music and real ale venues of Canal Quarter. In this sequel to that article, we use critical theory to show how the alternative, authentic space of vinyl, real ale, and live music has already been compromised by two conflicting hegemonic powers: the cooption of leisure into the economics of tourism and tourism policy, and the meaninglessness of cool capitalism (McGuigan, 2009) and Bauman's (2001, 2013) consumer society, which is the consequence of his "liquid modernity." We will do this by undertaking a critical analysis of those policies following Rose (1999), before providing some ethnographic field notes that illuminate the tension over meaning and authenticity (Bauman, 2013; MacCannell, 2013). Before we turn to the new data, we will describe our theoretical framework, and our methods.

\section{Theoretical Framework}

A number of scholars in tourism studies have argued for the salience of critical theory for making sense of the subject field. Tribe (2001) applied critical theory to his call for critical tourism studies, and has returned to the theme (Tribe, 2008). Tzanelli (2004) used Adorno and Horkheimer's (1997) culture industry to expand Urry's tourist gaze (1990) in a critique of The Lord of the Rings tourist industry in New Zealand. Skoll and Kostanje (2014) explored tensions over authenticity in the gentrification of Riverwest (USA) and El Abasto 
(Argentina). This contestation of tourism and leisure spaces is mapped out by our previous study of Skipton's Canal Quarter (Robinson \& Spracklen, 2019). The application of critical theory to tourism studies is still considerably niche. Most research in tourism studies is still focused on making and managing tourism more efficiently, and giving the tourist a more authentic and happy experience. There may be some attempt to explore the ethics of tourism in the face of climate change and unsustainable practices, but tourism is assumed to be a moral good, something that is a human need. The entire mobilities paradigm, for example, by shifting to poststructural ideas of agency, makes tourism something disconnected from the particular ideology that shapes culture and society today: modernity and capitalism.

The world today has obviously changed since the days of Marx, and the days of Adorno, but we would argue that this is not a significant change. We now have postindustrial economies in the West, but the global economy is still driven by capitalism (McGuigan, 2009), and liquid modernity has made everyone consumers (Bauman, 2001, 2013). We have more power in the hands of transnational corporations than nation-states, but elite classes still have power and accumulate wealth from the rest of us. These days people go on holiday by plane rather than by train or charabanc, but the idea of going on holiday remains a powerful one. Where does that idea of getting away on holiday come from? Modernity and capitalism. The 19th century saw work and leisure become strictly delineated, with leisure time and space strictly controlled by elites in nationstates: this was the moment when rational recreation, spectator sports, and tourism all emerge as ways to profit from the lower classes and keep them in control (Spracklen, 2011). Through modernity this has continued to operate as a form of false consciousness, an ideology imposed on us by a Gramscian hegemony (Gramsci, 1971). We all want to buy the latest piece of technology because we think this shows we are cool. We all go to work dreaming of our next holiday, and hope that our friends and family will validate our choice of holiday, whether we want to fit in with them or show off by finding some adventure that shows off our individuality and supposed agency. And as Adorno and Horkheimer (1997) showed, this passivity of the lower classes is achieved by the culture industry, which operates at the heart of modernity and late capitalism.

The culture industry is what Adorno and Horkheimer (1997) showed as a consequence of the rise of the factory and the machine on culture. Popular culture and the culture industry controlled by the nation-state emerged in the form of massproduced newspapers and books in the 19th century, but these spaces operated as a public sphere in which different ideologies and politics could still be expressed. At the time they were writing, popular music had started to replace what was then labeled as classical music as a music shared by people in the West (Spracklen, 2011). This was happening partly because of a number of technological advances. The first was the rise of the music recording, which allowed musicians to be captured forever on a physical artefact that could be reproduced and sold to consumers. The second technological advance was the invention of radio, and the rise of radio stations with radio audiences. Commercial radio stations needed to sell air time to advertisers, so needed to show they had listeners - so that meant playing short records that were popular. Popular music and radio were the first evidence of the totalizing culture industry in action, followed soon by film and television. Far more than newspapers, even ones controlled by the Establishment, these new tools of the culture industry, as shown by Arendt (2017), allowed totalitarian regimes to completely control every individual. The culture industry operates by fooling people into thinking they are not being controlled, that they have agency and power, that they live in a nation-state and a world-system that is fair and equal.

Gramsci (1971) showed how hegemonic control of the tools of the culture industry allowed the fascists to gain power in Italy, and retain power. But the culture industry is not just something that operates in fascist and totalitarian states. It operates in liberal democracies, too; in fact anywhere where elites in nation-states have had to abandon feudal myths or ties of religion for the instrumentality of constitutions. It operates even in this globalizing society. Tourism, then, may be understood as being part of that culture industry, because like leisure it is something that we think we do freely but in fact it is something that is given to us in a neatly packaged, mediated, and commodified package. 


\section{Methodology}

As with Robinson and Spracklen (2019), we have used ethnographic fieldwork in the Canal Quarter of Skipton, and more generally in the town. The research in that study took place over a year before the new fieldwork undertaken for this article, and was combined with semistructured interviews. We have collected new fieldwork informally over a period of 3 months in 2019, and combined this data collection with a policy analysis. The policy analysis has been undertaken using the critical reflections in Rose (1999) as a framing device. We have then used discourse tracing (LeGreco \& Tracy, 2009) to allow us to find new, emergent themes in the field and in the policy material. Some scholars have argued that qualitative research is weak because it is impossible to generalize or find some kind of objective truth about a subject. We recognize that there is some epistemological credence to this criticism, and social sciences are able to be more scientific if quantitative data analysis is applied to data collected. However, such data collection and analysis is not always appropriate. Qualitative research methods in collection and analysis are the most appropriate way to make sense of the contestation of meaning in tourism and leisure spaces (Adams, 2018).

\section{Policy Analysis}

\section{Tourism}

Skipton has been a part of Craven District Council, a district of North Yorkshire County Council (NYCC), since local government reorganization split it away from the old West Riding of Yorkshire in 1974. Skipton also has its own town council, which operates as a large parish council with some local decision-making powers. The upper dales beyond Skipton are part of the Yorkshire Dales National Park Authority (YDNPA). Finally, the area is part of the Leeds City Region or LEP, which is steered by the West Yorkshire Combined Authority (WYCA), and that includes Craven and other districts surrounding West Yorkshire. Skipton and Craven, then, remain in the remit of Leeds City Region-looking towards the urban center of the old West Riding - as well as being part of North Yorkshire, with its council offices based in Northallerton in the old North Riding of Yorkshire. Tourism is promoted by all of the local and regional authorities; they all think tourism into Skipton and Craven is a good thing because it helps the economy; even the National Park sees money in tourism, even if it talks about "sustainable" tourism in its strategic planning (YDNPA, 2016). For example, NYCC (2019) says, "Tourism contributes significantly to the North Yorkshire economy and we work to develop the county as a great place to visit all year round." Craven (2019a) says, rather pleadingly, "There are so many things to see and do in Craven we don't want you to miss out." For NYCC the benefit of tourism is clearly economic: tourism brings in visitors, which bring in money for the businesses lining up to benefit. NYCC has bought the instrumental rationality of tourism: it is worth doing because of the profits it makes, as well as because tourism is a part of the wider culture industry.

On the Craven District Council website, as we have said above, there is a page on Tourism (Craven, 2019a), but it is not sign-posted on the front page. It is subdivided into three sections: one on accommodation; one on Tourist Information Centers (TICs); and one that provides guides to different parts of the district. Craven wants to help visitors to come to all parts of the district, including the places such as Skipton and South Craven that are not in the spectacular limestone country, but it also seems to be offering its own residents help to become tourists in the National Park. The TICs are specifically listed as being for "visitors and the local community." This may feel like a policy that promotes the local community and well-being more broadly, but the TICs are funded to promote tourism. Behind the guise of community engagement and social welfarism there is cost-benefit analysis: the TICs operate to construct a sense of Yorkshireness - green dales, sheep, drystone walls (Spracklen, 2016, 2019) - that is commodified and sold to consumers (Bauman, 2013; McGuigan, 2009), whether they are locals or visitors.

One can see this construction of Yorkshire and Skipton in the website of Welcome to Yorkshire, which has the reputation of bringing Le Tour de France to Yorkshire. If someone was to come to Skipton as a tourist, this is one of the websites where one might find out about what there is to do in the town. This is what is written there at Yorkshire.com about food and drink: 
Whether you're returning from a day in the Dales or want to fuel up before you hit the castle, Skipton has a fantastic array of places to eat and drink. So take a seat for some awardwinning fish and chips, settle into a pint of fine ale or select from a tempting variety of national cuisines represented around town. (Welcome to Yorkshire, 2019c)

This is the only place where beer is explicitly mentioned in the pages on Skipton. The wording is rather odd- - "settle into" sounds like one is physically falling in the drink and it should be real ale not "fine ale," which is a meaningless term. However, the visitor gets the wider message. Skipton is where tourists to this part of the Yorkshire Dales should come to eat and drink. This is the town where you should come to spend money on cake, fish and chips or something more "fancy" ("a variety of national cuisines"), and on beer. But it is not just a page that lets us find our own place to eat and drink. The page mentions and links to two award-winning pubs and restaurants outside Skipton, as well the chippy and a tea room. Now the pub, the Angel, does real ale and great food, but the restaurant, Burlington's at the Devonshire Arms, is very pricey. Neither are in Skipton town center, and neither are for visitors who are looking for value. On the page is an advert for the Cotton Mill redevelopment: fancy new apartments in the building next to the one converted into offices for Craven. The message is clear: love it so much, you should move there. But the advert also shows us that the culture industry of tourism is even working to make the gentrification happen much faster.

Skipton Business Improvement District (BID), supported by the town council, the local chamber of commerce, and the district council says this about Skipton (Skipton BID, 2019) as a place to live:

Sunday Times Best Place to Live in Britain 2014, The Independent Britain's Happiest Place [source: Office of National Statistics 2017], the National Campaign for Courtesy awarded Skipton most Courteous Town 2016; and NABMA The Voice of Markets awarded Best Small Outdoor Market 2017 and Best Large Speciality Market 2018!

Skipton is a delightful place to live enabling you to enjoy the best of all worlds.

Make the most of living in a friendly market town with a range of activities from watching or playing sports of all kinds, to joining clubs and societies, going to the cinema or even a night out at the 'Little Theatre'.

As the Gateway to the Dales, the Yorkshire countryside is on your doorstep: you can enjoy walking, cycling, clay pigeon shooting, fishing or horse riding or just take a 'drive' to bask in the glorious scenery and views. (http://skiptonhub.uk/ about-us/)

Again, we get the main picture: Skipton BID wants to encourage more people to come to live in the town because the BID is about improving the town's economy, and the economy is driven by tourism, whether that is day-trippers on a coach or retirees coming up North with their earned wealth from the housing bubble in the South. At least Skipton BID is still able to offer the communicative leisure choice of amateur dramatics or just walking to enjoy the views, though the image is made more problematic when they suggest one can drive rather than take public transport. As the Yorkshire Dales National Park suggests, there are too many people driving into the Dales, and this is not sustainable: it is causing damage to roads and villages, and creating pollution and causing harm to the planet (YDNPA, 2016). Skipton BID is also playing a dangerous game with encouraging people to move to the town. People come to Skipton because they want to see the hills. Most of the hills around Skipton are not in the National Park, and the pressure to build new homes, new roads, and new employment sites is a policy consequence of pursuing economic development that will be catastrophic for tourism. New housing has spread along the fields below Skipton Moor, and more will be built along with an industrial estate on the Aire Gap flood plain. This is because economic development is everything, and all leisure, tourism, and culture is shaped by it, as we show next.

\section{Economic Development, Well-Being, and Leisure}

NYCC is formally responsible for social care in the district, and works in partnership with health authorities to promote well-being. In practice, health funding is incapable of meeting the needs of an ageing population in England, and in Skipton the same pressure of the market economy in health is found. What this means is there are no policies to use leisure and culture to promote well-being and 
happiness, or community cohesion and social inclusion. Skipton's leisure is formally the responsibility of Craven, which provides leisure centers and sports and recreation services, which are run as profit-making enterprises (though libraries are run by NYCC). Craven does not consider drinking or music as leisure activities, though it has legal powers in licensing that affect whether pubs and bars open, or whether live music is allowed (Robinson \& Spracklen, 2019). This power has allowed the rise of micropubs, and the bars that have live music, in the town. Craven is writing a Cultural Strategy; a news release (Craven, 2019b) claims that "Craven District Council is consulting on its draft Cultural Strategy, which sets out plans to improve the quality of life and strengthen the economy through promoting and supporting arts, heritage and culture in the district." If the Strategy was about improving well-being alone through culture that would have been fine. But the Strategy is deliberately pitched as something that is about well-being and the economy. This may be a deliberate move by council officers to appease their Conservative-lead councilors. But it plays into the wider narrative about the culture industry (including tourism) being the only thing that matters, because the district has to turn a profit.

The Leeds City Region (LEP) Strategic Economic Plan 2016-2036 is an enormous document that sets out a long range of targets, strategies, and actions for the entire region. This is what it has to say about Skipton and Craven:

Like many rural areas, Craven faces challenges such as an ageing population, high housing costs, and rural isolation - often as a result of poor public transport connectivity and less well developed physical and digital infrastructure. Skipton, the district's principle [sic.] town, enjoys low rates of crime, top-class schools, good transport links to Bradford and Leeds, a vibrant retail offer and beautiful surrounding countryside. Although the traditional economy retains a predominantly rural flavour; it has diversified, with notable strengths in financial and professional services and leading firms in the health sector. Challenges include low incomes in more rural and remote parts of the district, in part linked to the extent of the agricultural and tourism sectors. (LEP, 2016, p. 39)

Skipton, then, is seen as a strong site of economic activity with clear links to Leeds, but the rural fringes of the Dales are flagged as being reliant on agriculture and tourism. It is ironic that the LEP is critical of a narrow focus on tourism in the Dales, yet neglects to say that tourism and economic development is equally problematic in Skipton. Furthermore, Craven as a whole has an ageing population, and public transport within it is poor. The paragraph also mentions the lack of digital infrastructure. The LEP believes that digital and the creative industries are the way to ensure development is sustainable. If everybody is working from a laptop in their home or a vegan café, then at least there is no need to build better public transport, and the roads will be less busy for the day-trippers and those who wish to retire there. As it says elsewhere, the plan:

is about creating a strong, productive and resilient economy where a radical uplift in business competitiveness, productivity and profits goes hand in hand with access to good jobs that pay higher wages, and where all residents have access to opportunity and enjoy improved quality of life. The value of this is clear-people are better off, the local economy is transformed and boosted, the environment is improved, society is fairer and government is able to spend less on welfare and public services. (LEP 2016, p. 13)

Creative industries are the new solution to the lack of real opportunities and real social inclusion. They are the culture industry under a new hipster brand (McGuigan, 2009; Michael, 2015). Craven worked with South Lakeland District Council on an initiative called Great Place: Lakes and Dales, designed to promote the idea that the area is a great place for young creative types to live and work. Great Place (2018) is a commissioned piece of research with such people that claims: "The creative economy, and especially a place-making focus, can support positive change. $25 \%$ of $16-34$ year olds are involved in creative and cultural industries."

The research report says it is objective, but the data collection was not random: the report says that respondents were interviewed in focus group discussions, on social media, at visitor centers, and through a panel survey designed to be "representative" of the area's demographics (so not random, so not objective). The figure of $25 \%$ is questionable. The report, though, does point out the reality of living in the district. Many of the respondents struggle 
to find meaningful employment, many struggle to get to see gigs or attend other cultural events. But they also recognize the beauty of their surroundings, and many of them would rather live in the district than in a city. Elsewhere on the website it shows a set of young creative types, and tells us:

\begin{abstract}
Whether they've grown up here or discovered the area as an adult, our creative champions all have one thing in common, they've decided that Lakes and Dales is the only place for them! . . . we call them our creative champions - people who love and are dedicated to the rural communities in which they live and work. (Great Place, 2019)
\end{abstract}

The initiative, then, has already limited its focus. The report discusses well-being, identity, community, and culture. But the website instead gives us a host of hipster entrepreneurs who will act as inspirational agents for young people ear-marked for the culture industry in its new guise of tourism and culture.

\section{Field Notes: Tourism and Leisure Spaces}

In Robinson and Spracklen (2019) we identified the rise of a communicative leisure space in the pubs in Skipton's Canal Quarter, linked to live music and real (cask-conditioned) ale. Skipton was one of the northern working-class towns that never lost cask-conditioned ale when most of the beer industry converted to pasteurized keg bitter then keg lager (Spracklen, Laurencic, \& Kenyon, 2013). Cask-conditioned real ale is different to craft beer (which is generally pasteurized and sold in kegs) and is unique to this country, though it shares with the craft beer movement ideas of locality and authenticity. The Campaign for Real Ale (CAMRA) was set up in the 1970s to defend real ale, and has been influential in ensuring real ale has flourished around the country in the last 30 years (Thurnell-Read, 2018). Skipton has always been renowned for its real ale pubs. In recent years, Skipton gained a number of micropubs, first being the Beer Engine, small real ale pubs with relaxed licensing rules that often open in empty shops. Another micropub, the Sound Bar, combined real ale with second-hand vinyl, and this pub was the instigator of live music nights. As we were finishing Robinson and Spracklen (2019), the Sound Bar was sold on to a new owner, and other micropubs were appearing. The following field notes give a flavor of the changes, the tension between different tourists and drinkers, gentrification, and the commodification of tourism and leisure.

02 March 2019, 13:35

Skipton High Street. Very busy even though the weather forecast is for wind and rain. Push through to the Canal Quarter. The new bistro where Spencer's café was is doing okay. Who would eat fine dining there?

Coach Street 'pop-up' TIC, 13:40

I am the only person in it. There are no leaflets on anything associated with real ale, or music other than the classical music concerts that used to be in the Town Hall. Outside it is fairly quiet. Notice that the mill shop is no longer to let. Elwood's Kitchen, another new fancy dining place, is busy. I note they have craft beer on: keg Craven Bitter from Dark Horse, which is a real ale brewery (Mill Shop: understand there's a planning application in for change of use to accommodate yoga classes. All adds to an 'alternative' Canal Quarter vibe?)

Boat House, 13:42-14.35

Fairly quiet in the $\mathrm{BH}$. No one outside. Inside look like all real ale types at first glance. No Craven CAMRA magazines. CAMRA membership forms, Lunesdale Drinker left by other CAMRA branch visiting. Half of the bar (a new extension) now devoted to keg beer: lager, cider, but also craft beer. This is all designed like a craft beer bar. They are serving Wild Child something from Leeds. I buy real ale from Wishbone in Keighley. (Since John 'Spike' Gartan left, there's no one on the staff who promotes real-ale.) Posters for Live Music Nights and Jam Sessions prominent. Also a poster for a Skipton Beer Circle evening: craft beer organised by the Growling Shrew craft beer shop, no real ale.

Now notice one younger couple drinking lager (her) and craft beer (him). On the table next to me is an older man with a tee-shirt that says: Think analog (sic.). The picture is a stylised vinyl record player. Biker beard, beer belly. Him and his friends all have Lancashire accents. Not local. I realise most of this group is drinking lager or cider-including analog man. I look again and realise: they are all on lager or cider.

In fact there are only three drinking real ale out of twelve and one of those is me. Still people outside on the 30 minute boat trip, even though it is raining.

17 March 20192.15 pm: Boat House (Sunday-St. Patrick's Day) 
Glyn (organiser) on guitar and bodhran, together with 2 of the regulars including Barry (and another male guitar picker) and an unfamiliar female fiddle player are gathered at the first tables inside the doorway as usual. The regulars are drinking real ale, the other locals drink ale, lager and cider, and the visitors drink a mixture of ale, G\&T and soft drinks. At the table beyond the players, three generations of a local family group are gathered including an off-duty bar maid, her mother, a young female friend, 2 older males, 2 young children and 2 dogs. They also have a tambourine and some percussive shakers at the table.

The rest of the tables around us are occupied by what appear to be mainly day visitors, mostly middle-aged couples. In keeping with St Patrick's Day, Glyn and his jam colleagues play wellknown Irish songs: 'Black Velvet Band'; 'The Wild Rover'. Some of the customers join in the choruses. The fiddle player then goes into a jig, and the women at the next table start to dance along to it in the walkway. Without any communication between themselves and Glyn's players, the couple opposite to me start singing and strumming an Everly Brothers song, apparently reading the lyrics and chords from sheet music on their tabletop music stand. One of the women at the table in between the 2 groups of players takes up the tambourine and her and a friend attempt to sing along.

This is new to me. From then on the 2 musician groups continue to perform alternately-Glyn's 'official' jamming group playing a couple of traditional folk songs or instrumentals, interspersed with a pop song by the 2 visitors.

$4.30 \mathrm{pm}$ : The music-making wraps up and the bar starts to thin out. Overall, around two-thirds of the customers that are left are day visitors. I follow 2 of my companions over to the Beer Engine.

$5 \mathrm{pm}$ : A few of the early-evening regulars begin to drift in-all real ale drinkers. These are part of a group who frequent the BE at different times of the week but make a particular point of gathering together on Sunday evenings as a favourite meet up time. Sunday evenings are a time of the week at which the BE provides a particular feeling of community - once the weekend visitors have gone home and regulars can relax in familiar company.

\section{March 2019}

Wandering around on Sunday lunchtime. Most of the cafés look full. It is a clear day and there are lots of people walking up and down the High Street, though not at summer levels yet. The big pubs are all doing well. Inside Early Doors I can see people I recognise: CAMRA members. The new micropub is still not open, but the bar has been put up. Beer Engine full. Boat House halfempty. Sound Bar full, no one browsing vinyl. Outside the Sound Bar a long list of forthcoming events. A sign that reads 'the Heart of the Skipton Music Scene'. Across the road, the Cock and Bottle has a poster advertising live music. Along the road and across the canal, Cooper's café, normally a place that reeks of bacon for workers at the Mill, now also offers live music on an evening.

\section{Discussion}

When Skipton's live music scene emerged in the pubs off the Canal Quarter, this was a form of leisure and tourism that was literally removed from the day-trippers and cyclists who populate Skipton's High Street. It has emerged out of range of the tourism policies of the various local authorities, and it is still not mentioned in the local TIC, or on the various websites promoting Skipton. The scene was based around the supposed authenticity of real ale, and the second-hand vinyl records in the Sound Bar. This was a form of cool capitalism (McGuigan, 2009), driven by people who saw in the conflation of proper beer, proper live music, and old vinyl a way to make money from locals and tourists seeking something different to the Wetherspoon's or stand-up lager places that are routinely the survivors in every other English high street. This was a fantasy driven by the hegemonic power of the culture industry (Adorno \& Horkheimer, 1997). There is no moral difference between real ale pubs and lager pubs - they are both products of modern capitalism - but the real ale spaces can be used to resist some of the most egregious forms of commodification in the leisure and tourism that surrounds drinking culture. Real ale drinkers support local businesses and reject transnational corporations, and reject tourist guidebooks and adverts for official CAMRA publications. Similarly, listening to live music or buying second-hand vinyl can be seen as a reaction against the streaming and talent shows of the mainstream music industry, even if such reaction is still ultimately constrained by the wider culture industry. The Beer Engine's small space, lack of canned music, and focus only on real ale hand-pumps means that lager drinkers and people "on the piss" are actively discouraged 
from getting in. As such, it is still a place for real ale tourists and locals to meet and share their appreciation of the authentic beer while simultaneously awarding themselves distinction (Bourdieu, 1984; Thurnell-Read, 2018). The Boat House, by contrast, has both canned music and lager, and has now extended its range to serve keg, craft beer. As for the Sound Bar, it is now a place where people drink huge amounts and music is played at high volumes, and very little browsing of vinyl is possible: though some racks are still there. Meanwhile, all the pubs off the High Street in Skipton have become increasingly popular, and increasingly busy, as people come for the drinking, and the music. The Boat House, right beside the canal, was always full as soon as it opened; now it has become a venue that is more likely to be full of people drinking anything but real ale. The change in management and the addition of keg dispensers means it is following another fashion in the culture industry: the embrace of craft beer and the hipster.

Other things have happened since we published our first paper on the Canal Quarter that point towards the embrace of a more ersatz authenticity, which is more New York than North Yorkshire. The Quarter already has a dance venue and will now have a yoga one. It is becoming an alternative, cool, hipster place, like Hebden Bridge or Brooklyn. A number of fine dining places have opened in the space, serving fancy lunches and dinners that look good on Instagram. One of these places only serves craft beer. A shop serving craft beer-not real ale - has appeared, and has started to sell itself as the place for beer as if real ale was something that had never existed, as if Skipton did not have any real ale pubs. And finally, other pubs and eating places have started to put on live music, tapping into the idea that the Canal Quarter is a happening place. We can see that the research report and website of Great Place is an attempt to commodify and monetize the live music scene in the real ale micropubs. The people behind the initiative want Skipton to become the new hipster capital, and are already providing ideas about how money can be made out of it.

Hipsterism and the alternative cultural industries might be said to be counterhegemonic aimed at travelers not tourists (Michael, 2015). But that is a category error: they are products of the culture industry that fools people into thinking they are being alternative and counterhegemonic, when in fact they are just reproducing the tools of their oppression (Bauman, 2013).

For policy-makers trying to make life better, the limitations of existing policies around tourism and leisure are clear. The only real driver at a local and regional level is economic development. Skipton has to make money, either from the cultural industries, or from tourism, or from building houses. Policy-makers like the idea of micropubs and vinyl shops, and seemingly want more of that kind of tourism than the coach trips that feed the businesses on High Street. But both kinds of tourism are problematic, because all tourism is a product of capitalism and hegemony, and all tourism brings exploitation, environmental damage, and the commodification of local culture and leisure spaces (Skoll \& Korstanje, 2014).

\section{Conclusion}

In this second analysis of the Canal Quarter in Skipton, our findings show that it is a contested space that demonstrates the shift to liquid modernity and the consumer society (Bauman, 2013). Liquidity here operates to destroy the Habermasian communicative leisure we saw earlier (Robinson \& Spracklen, 2019). That previous communicative leisure space-the micropubs serving real ale - was itself contested and shaped by capitalism, and it was the product of exclusionary constructions of gender, but it was nonetheless a space for working-class "locals" to feel belonging. This space has been coopted by people looking to make profit from tourism and the culture industry (Adorno \& Horkheimer, 1997). Already there are chancers opening up new micropubs in Skipton, which have live music, craft beer, and real ale. As these pubs get busier and make more money from craft beer (which sells at a higher price than real ale), the danger will be that they stop serving real ale. If the pubs are too crowded, the good-natured community of acoustic sessions will be replaced by electric music. This will all serve to constrain the older locals from being in this space. The logic of Bauman's (2013) consumer society operates here to shape, limit and commodify the canal and the bars (Skoll \& Korstanje, 2014). Everyone 
who enters this space is trying to find meaning. In liquid modernity, as Bauman (2013) suggests, everybody who can is on the move finding meaning. But that meaning here is mediated by the hegemony of cool capitalism (McGuigan, 2009). Here, there is no authentic leisure space, only different agents claiming to sell it: to policy-makers, to tourists, and to incomers pursuing a fantasy of Yorkshire life.

\section{References}

Adams, K. M. (2018). Local strategies for economic survival in touristically volatile times: An Indonesian case study of microvendors, gendered cultural practices, and resilience. Tourism, Culture \& Communication, 18(4), 287-301.

Adorno, T. W., \& Horkheimer, M. (1997). Dialectic of enlightenment. London, UK: Verso.

Arendt, H. (2017). The origins of totalitarianism. London, UK: Penguin.

Bauman, Z. (2001). Consuming life. Journal of Consumer Culture, 1(1), 9-29.

Bauman, Z. (2013). Consuming life. London, UK: John Wiley \& Sons.

Bourdieu, P. (1984). Distinction. London, UK: Routledge.

Craven. (2019a). Tourism. Retrieved from https://www.cravendc.gov.uk/tourism/

Craven. (2019b). Consultation on Craven's cultural strategy: Have your say. Retrieved from https://www. cravendc.gov.uk/news/news-archive-folder/february2018/consultation-on-craven-s-cultural-strategy-haveyour-say/

Gallent, N., \& Robinson, S. (2012). Community perspectives on localness and 'priority' housing policies in rural England. Housing Studies, 27(3), 360-380.

Gramsci, A. (1971). Selections from prison notebooks. London, UK: Lawrence and Wishart.

Great Place. (2018). Research: highlights research report. Retrieved from https://www.lakesanddales.org/wp-content/ uploads/Great-Place-Lakes-and-Dales-research-highlights.pdf

Great Place. (2019). Creative champions. Retrieved from https://www.lakesanddales.org/creative-champions

Habermas, J. (1984). The theory of communicative action, Volume One: Reason and the rationalization of society. Cambridge, UK: Polity.

Habermas, J. (1987). The theory of communicative action, Volume Two: The critique of functionalist reason. Cambridge, UK: Polity.

LeGreco, M., \& Tracy, S. J. (2009). Discourse tracing as qualitative practice. Qualitative Inquiry, 15(9), $1516-1543$.

LEP. (2016). Leeds city region strategic economic plan 2016-2036. Retrieved from https://www.lepnetwork.net/ media/1119/leeds-city-region-sep.pdf
MacCannell, D. (1973). Staged authenticity: Arrangements of social space in tourist settings. American Journal of Sociology, 79(3), 589-603.

MacCannell, D. (2001). Tourist agency. Tourist Studies, 1(1), 23-37.

MacCannell, D. (2013). The tourist: A new theory of the leisure class. Berkeley, CA: University of California Press.

McGuigan, J. (2009). Cool capitalism. London, UK: Pluto Press.

Michael, J. (2015). It's really not hip to be a hipster: Negotiating trends and authenticity in the cultural field. Journal of Consumer Culture, 15(2), 163-182.

North Yorkshire City Council. (2019). Tourism. Retrieved from https://www.northyorks.gov.uk/tourism

Office for National Statistics. (2017). Personal well-being in the UK: April 2016 to March 2017. Retrieved from https://www.ons.gov.uk/peoplepopulationandcommunity/wellbeing/bulletins/measuringnationalwellbeing/ april2016tomarch2017

Robinson, D., \& Spracklen, K. (2019). Music, beer and performativity in new local leisure spaces: Case study of a Yorkshire Dales market town. International Journal of the Sociology of Leisure, 2, 329-346. doi: https://doi. org/10.1007/s41978-018-00029-5

Rose, N. (1999). Powers of freedom: Reframing political thought. Cambridge, UK: Cambridge University Press.

Skoll, G. R., \& Korstanje, M. (2014). Urban heritage, gentrification, and tourism in Riverwest and El Abasto. Journal of Heritage Tourism, 9(4), 349-359.

Spracklen, K. (2011). Constructing leisure: Historical and philosophical debates. Basingstoke, UK: Palgrave.

Spracklen, K. (2016). Theorising northernness and northern culture: The north of England, northern Englishness, and sympathetic magic. Journal for Cultural Research, 20(1), 4-16.

Spracklen, K. (2019). Cycling, bread and circuses? When Le Tour came to Yorkshire and what it left behind. Sport in Society. Advance online publication. doi: https://doi.org/ 10.1080/17430437.2019.1673735

Spracklen, K., Laurencic, J., \& Kenyon, A. (2013). 'Mine's a pint of bitter': Performativity, gender, class and representations of authenticity in real-ale tourism. Tourist Studies, 13(3), 304-321.

Thurnell-Read, T. (2018). The embourgeoisement of beer: Changing practices of 'real ale' consumption. Journal of Consumer Culture, 18(4), 539-557.

Tribe, J. (2001). Research paradigms and the tourism curriculum. Journal of Travel Research, 39(4), 442-448.

Tribe, J. (2008). Tourism: A critical business. Journal of Travel Research, 46(3), 245-255.

Tzanelli, R. (2004). Constructing the 'cinematic tourist': The 'sign industry' of The Lord of the Rings. Tourist Studies, 4(1), 21-42.

Urry, J. (1990). The tourist gaze: Leisure and travel in contemporary societies. London, UK: Sage.

Welcome to Yorkshire. (2019a). Skipton. Retrieved from https://www.yorkshire.com/places/yorkshire-dales/ skipton 
Welcome to Yorkshire. (2019b). We are Welcome to Yorkshire. Retrieved from https://industry.yorkshire.com/about-us

Welcome to Yorkshire. (2019c). Food and drink. Retrieved from https:/www.yorkshire.com/places/yorkshire-dales/ skipton/food-and-drink

Whittle, M., Lomax, N., Heppenstall, A., \& Brerton, S. (2017). Equitable or elitist? The social impact of the 2014 Tour de France Grand Départ. Area, 49(1), $60-68$.

Yorkshire Dales National Park Authority. (2016). Yorkshire Dales National Park Local Plan 2015-2030. Retrieved from https://www.cravendc.gov.uk/media/5971/007yorkshire-dales-national-park-local-plan-text-2016.pdf 
Copyright of Tourism Culture \& Communication is the property of Cognizant, LLC and its content may not be copied or emailed to multiple sites or posted to a listserv without the copyright holder's express written permission. However, users may print, download, or email articles for individual use. 